\title{
The effect of merger anticipation on bidder and target firm announcement period returns
}

\author{
Marcia Millon Cornett ${ }^{\mathrm{a}}$, Başak Tanyeri ${ }^{\mathrm{b}}$, Hassan Tehranian ${ }^{\mathrm{c}, *}$ \\ a Bentley University, Waltham, MA 02452, United States \\ b Bilkent University, Bilkent, Ankara, Turkey \\ c Boston College, Chestnut Hill, MA 02467, United States
}

\section{A R T I C L E I N F O}

\section{Article history:}

Received 29 April 2010

Received in revised form 25 October 2010

Accepted 25 October 2010

Available online 11 November 2010

\section{JEL classification:}

G34

G30

\section{Keywords:}

Mergers and acquisitions

Financial performance

Corporate governance

\begin{abstract}
A B S T R A C T
This paper examines investors' anticipation of bidder and target merger candidacy and if investor anticipations about candidacy affect the distribution of value between bidder and target firm shareholders. We find that bidder firms can be predicted more accurately than target firms. To investigate how merger announcement period returns are distributed among bidder and target shareholders, we control for different degrees of predictability in bidder and target selection and find that the difference between bidder and target firm three-day cumulative abnormal returns around a merger announcement decreases significantly. Thus, the evidence supports the hypothesis that the asymmetry in investor anticipations about merger candidacy causes disparity in bidder and target firm announcement period abnormal returns.
\end{abstract}

(C) 2010 Elsevier B.V. All rights reserved.

\section{Introduction}

This paper investigates the extent to which investors anticipate bidder and target firm merger candidacy and if investor anticipations about candidacy affect the distribution of announcement period returns between bidder and target firm shareholders. We link anticipations about merger candidacy to stock price announcement period returns using a twostage model with an adjustment for simultaneous equations bias. The selection equations model bidder and target candidacy. The structural equations model bidder and target cumulative abnormal returns around merger announcements. We then investigate if and how predictability in merger candidacy affects bidder and target cumulative abnormal returns.

We find that investors can predict bidder firms more successfully than target firms. As a result, some bidder firm, merger-related information is stale at the time of announcement. However, the information that merger announcements reveal about targets is less stale. As a consequence of the difference in the freshness of information revealed at a merger announcement, it is not surprising that previous research has found that target firm CARs are larger in magnitude than bidder CARs. Without controlling for differences in predictability of merger candidacy, it is incorrect to conclude that target shareholders capture the majority of the value gains that mergers generate. Once we account for greater predictability in bidder firm candidacy, the difference between bidder and target firm three-day cumulative abnormal returns around a merger announcement decreases significantly. Thus, the evidence supports the hypothesis that to some extent asymmetry in investor anticipations about merger candidacy causes disparity in bidder and target firm announcement period abnormal returns.

\footnotetext{
* Corresponding author. Tel.: + 16175523944.

E-mail addresses: mcornett@bentley.edu (M.M. Cornett), basak@bilkent.edu.tr (B. Tanyeri), hassan.tehranian@bc.edu (H. Tehranian).
} 
Surveying merger studies, Jensen and Ruback (1983), Jarrell et al. (1988), and Andrade et al. (2001) report that announcement period cumulative abnormal returns to target firm shareholders are substantial (around 20\%), whereas cumulative abnormal returns to bidder firm shareholders are insignificant (around 0\%). Netter et al. (2010) find that the filters used to construct bidder and target samples significantly affect CARs. In their sample, that covers 288,406 deals, three-day bidder CARs are significant at 1\%: acquirer returns at the deal announcement are negative only when studies screen down to large public firms buying large public firms. However, Netter et al. note that, over their period of study, deals of over a $\$ 1$ billion make up only $2.0 \%$ of the transactions, but $70.2 \%$ of the reported deal values. Thus, the question remains, why target shareholders seem to be enjoying the majority of value generated in the vast majority (measured by deal value) of mergers. ${ }^{1}$ A crucial assumption in event studies of merger announcements is that investors learn mergerrelated information in a short window of time. However, if investors can predict merger announcements, this important assumption is violated. Indeed, Billett and Qian (2008) find evidence that the market anticipates future acquisition deals based on the CEO's acquisition history and impounds such anticipation into stock prices. Similarly, Song and Walkling (2000) find that rivals of initial acquisition targets earn abnormal returns because of the increased probability that they will be targets themselves. To the extent that investors anticipate bidder and target firm candidacy, abnormal returns around merger announcements do not measure the market's full assessment of the benefits that shareholders enjoy. Within the event window, announcement period abnormal returns measure investors' responses only to unanticipated information that announcements convey.

Several empirical studies investigate investor anticipations in the context of merger programs (Schipper and Thompson (1983), Asquith et al. (1983), Malatesta and Thomson (1985), Fuller et al. (2002), Ismail (2005), and Song and Walkling $(2000,2008))$. The focus of these studies is to find a single characteristic that differentiates anticipated and unanticipated bidder firms or anticipated and unanticipated target firms. These papers then develop a candidacy model that is limited to a single instrumental variable. Edmans et al. (2009) also look at investor anticipation of a single firm. However, they take a unique approach in which a firm's discount to its potential value significantly attracts takeovers (the trigger effect), but market expectations of an acquisition cause the discount to shrink (the anticipation effect). Even if a low valuation attracts an acquisition, a high valuation may indicate that the market believes an acquisition is probable, thus attenuating any relationship between valuation and takeover probability found in the data. They call the combination of these effects the feedback loop. While the examination of a single firm as a bidder or target candidate represents an easy and intuitive way to address investor anticipations, a model that considers the effect of investor anticipations about both bidder and target candidacy, rather than on either bidder or target candidacy, and that allows for multiple motives of mergers, can more accurately measure investor anticipations about candidacy. ${ }^{2}$

The contribution of this paper is fourfold: i) we investigate the effect of investor anticipations on both bidder and target candidacy, rather than on either bidder or target candidacy, to allow us to examine how any value that mergers generate is divided between bidder and target shareholders, ii) we develop a more complete model of investor anticipations of both bidder and target firm candidacy by incorporating multiple merger motives; iii) we analyze how investor anticipations about candidacy affect stock price responses to merger announcements; and iv) we investigate what stock price responses to merger announcements reveal about managerial motives.

The remainder of the paper is organized as follows. Section 2 outlines the research methodology and describes the data. Sections 3 and 4 report and interpret results of the models of merger candidacy and merger announcement cumulative abnormal returns, respectively. Finally, Section 5 concludes the paper.

\section{Methodology and data}

This section develops the two-equation framework used to model investor anticipations of merger candidacy and of bidder and target firm abnormal returns at a merger announcement. The sample used to test the model is then described.

\subsection{Two-equation model of investor anticipation of and stock price responses to merger announcements}

Managers choose to merge only when it serves their interests. Thus, investors observe merger announcements only when manager merger-related benefits are sufficiently high. Prior to a merger announcement, investors can only assess observable information about motives of firm management to merge. Accordingly, Eq. (1) models managerial choice to be or not to be involved in a merger. Specifically, we let $M_{S}^{*}(S=B-$ Bidder, $T-T$ arg et, $N$-Nonmerging firm)denote imperfectly observable benefits that firm management realizes from bidding, receiving bids, and abstaining from mergers, respectively. The regressors, $X_{1}$, are firm and industry characteristics that investors might use to measure managerial merger-related benefits and $X_{1} \gamma_{S}$ are

\footnotetext{
1 Bhagat et al. (2005) find that bidders on average pay the fair value for shares they purchase in tender offers. Their model finds that improvements from tender offers are on average perceived by investors to be positive and substantially larger than estimates from previous studies.

${ }^{2}$ Cremers et al. (2009) create a "takeover factor," buying (selling) firms with a high (low) takeover likelihood, which generates "abnormal" returns. They find that the takeover factor helps explain cross-sectional differences in equity returns. If firms are more likely to acquire when there is more free cash or lower required rates of return, the targets become more sensitive to shocks to cash flows or the price of risk. Ceteris paribus, firms exposed to takeovers have different rates of return than protected firms.
} 
investor's estimates of benefits that accrue to management in state S. Finally, $\varepsilon_{S}$ are the unanticipated or unobservable merger benefits in state $S$.

$$
\begin{array}{ll}
M_{S}^{*}=X_{1} \gamma_{S}+\varepsilon_{S} ; & \text { if } M_{B}^{*}>\max \left(M_{T}, M_{N}\right) \text { the firm proposes a merger bid } \\
& \text { if } M_{T}^{*}>\max \left(M_{B}, M_{N}\right) \text { the firm solicits / recieves a merger bid } \\
& \text { if } M_{N}^{*}>\max \left(M_{T}, M_{B}\right) \text { the firm abstains from merger activity }
\end{array}
$$

Investors cannot directly observe managerial motives or benefits associated with a state $\left(M_{S}^{*}\right)$. However, investors do observe merger announcements. We define $M$ as an indicator variable that takes a value of 0 if a firm proposes at least one merger bid in the next year, 1 if a firm solicits/receives at least one merger bid in the next year, and 2 if a firm neither proposes nor receives a merger bid in the next year. We then run multinomial regressions of $M$ on predictors of merger candidacy, $X$, to estimate investor's anticipations of bidder and target candidacy.

In turn, merger announcements disclose previously unobservable information about motives of firm management to investors. Managerial motives mix a desire to generate shareholder value with the pursuit of opportunistic benefits that are good for bidder firm managers but may destroy firm value. If investors determine that managerial motives to merge emphasize shareholder value creation, bidder firm stock price responses to merger announcements should be positive. If investors determine that managers are predominantly pursuing opportunistic benefits with a merger that result in firm value reductions, stock price responses to merger announcement surprises should be negative. Thus, managers may be motivated to merge in order to generate shareholder value and/or to pursue opportunistic benefits that benefit managers but destroy firm value. Thus, investors observe merger announcements (i.e., $M$ takes on a value of zero or one) only when manager merger-related benefits are sufficiently high $\left(M_{B}^{*}>\max \left(M_{T}^{*}, M_{N}^{*}\right)\right.$ or $\left.M_{T}^{*}>\max \left(M_{B}^{*}, M_{N}^{*}\right)\right)$. As a result, merger announcements disclose direct information about the merger as well as indirect information about managerial motives driving the merger.

Eqs. (2) and (3), respectively, model bidder and target cumulative abnormal returns (CARs) that are conditional on firms proposing or receiving a merger bid (i.e., $C A R_{B} \mid M_{B}^{*}>\max \left(M_{T}^{*}, M_{N}^{*}\right)$ and $\left.C A R_{T} \mid M_{T}^{*}>\max \left(M_{B}^{*}, M_{N}^{*}\right)\right)$. In this model, merger announcements reveal previously unknown information such as the identity of the merger partners and terms of the merger contract $\left(X_{2 B}\right.$ and $\left.X_{2 T}\right)$, as well as about previously unobservable managerial motives $\left(\varepsilon_{B} \mid M_{B}^{*}>\max \left(M_{T}^{*}, M_{N}^{*}\right)\right.$ and $\varepsilon_{T} \mid M_{T}^{*}>\max \left(M_{B}^{*}\right.$, $\left.M_{N}^{*}\right)$ ). The inferences drawn about managerial motives for a merger influence how investors price the post-announcement enterprise. Finally, $\eta_{B}$ and $\eta_{T}$ are the error terms in the regression equations.

$$
\begin{aligned}
& C A R_{B} \mid M_{B}^{*}>0=X_{2 B} \beta_{B}+\left(\varepsilon_{B} \mid M_{B}^{*}>\max \left(M_{T}^{*}, M_{N}^{*}\right)\right)+\eta_{B} ; \\
& C A R_{T} \mid M_{T}^{*}>0=X_{2 T} \beta_{T}+\left(\varepsilon_{T} \mid M_{T}^{*}>\max \left(M_{B}^{*}, M_{N}^{*}\right)\right)+\eta_{T} .
\end{aligned}
$$

A problem with the model in Eqs. (2) and (3) is that we are using a nonrandomly selected sample to estimate behavioral relationships surrounding the choice to merge. That is, we analyze only those firms that chose to enter a merger. We do not (and cannot) identify and analyze those firms that chose not to enter a merger. This procedure results in a specification bias that arises because of a missing data problem, i.e., the regressions estimated on the selected sample of merging firms do not estimate population regression functions. In other words, the regressions in Eqs. (2) and (3) suffer from a simultaneous equations bias in that they confound the behavioral parameters of interest with parameters of the function determining the probability of entrance into the sample.

Heckman (1979) develops a two-stage binary-choice selection model that estimates behavioral functions using least squares methodology and is free from this simultaneous equations bias. Specifically, Heckman's "lambda" adjusts for the simultaneous equations bias that arises in a single-equation structural model when the structural and selection equations are influenced by the same variables. Lee (1982 and 1983) develops a two-stage polychotomous-choice selection model in which the merger decision is a polychotomous choice. Lee (1982) develops an instrumental variable (henceforth, the surprise instrument, SI, which is intuitively the counterpart of Heckman's lambda in a polychotomous-choice selection model) using the parameter estimates of the candidacy model. We use Lee's (1982) procedure to study how investor anticipations influence stock market responses to merger announcements. Specifically, in the bidder and target CAR Eqs. (2) and (3), the surprise instruments are inverse transformations of the probability that a firm proposes or receives a merger bid, respectively. The greater the surprise in the merger announcement, the greater is the information revealed about unanticipated merger motives, and the larger is the surprise instrument. ${ }^{3}$ Hence, the surprise instrument is a measure of the extent to which a merger announcement surprises the market. As in Lee (1983), we let

$$
\text { surprise instrument }_{S}=\frac{\varphi\left(\Phi^{-1}\left(F_{S}\left(X_{1} \gamma_{S}\right)\right)\right)}{F_{S}\left(X_{1} \gamma_{S}\right)}, \quad S=B, T \text {, }
$$

\footnotetext{
${ }^{3}$ It should be noted here that since the surprise instrument is a function of the error term from the first stage regression, it only captures the market surprise to the extent that the econometric specification of the first stage matches investors' perception about bidder and target candidacy.
} 
where $\varnothing$ and $\Phi$ are, respectively, the density and distribution functions for a standard normal variable, and,

$$
F_{S}\left(X_{1} \gamma_{S}\right)=\operatorname{Prob}\left(\varepsilon_{S}<\varepsilon\right)
$$

Thus, Eqs. (4) and (5) represent second stage structural models of bidder and target CARs, respectively:

$$
\begin{aligned}
& C A R_{B} \mid M_{B}^{*}>0=X_{2 B} \beta_{B}+S I_{B} \beta_{S I, B}+S I_{B} D_{B C A R} \beta_{S I, B C A R}+\eta_{B} \\
& C A R_{T} \mid M_{T}^{*}>0=X_{2 T} \beta_{T}+S I_{T} \beta_{S I, T}+S I_{T} D_{T C A R} \beta_{S I, T C A R}+\eta_{T} .
\end{aligned}
$$

A priori we cannot assign a negative or positive coefficient estimate to the surprise instrument. ${ }^{4}$ This is because unanticipated motives for a merger can be a mix of the manager's motives to generate shareholder value and to obtain opportunistic managerial benefits. The coefficient on the surprise instrument would be positive when investors assess that manager's motives for entering a merger are to promote the interests of shareholders more than to obtain opportunistic benefits that would harm share value. The coefficient on the surprise instrument would be negative when investors assess that manager's motives for entering a merger are to obtain opportunistic benefits that would harm share value more than to promote the interests of shareholders. In other words, anticipated destructive deals should have a negative coefficient on the surprise instrument (and positive for value enhancing deals). This suggests that the variance of reactions is also a function of the surprise. To address this, we generate an indicator variable that takes the value one when CAR is positive and zero when CAR is negative $\left(D_{B C A R}\right.$ and $\left.D_{T C A R}\right)$. We then interact this variable with the surprise instrument in bidder and target regressions. Thus, the coefficient on the surprise instrument is for negative CAR deals, while the coefficient on the surprise instrument plus the coefficient on the interaction variable is for positive CAR deals.

Econometrically, the functional form of the surprise instrument (or Heckman's lambda) allows for the identification of the twostage selection model. Further, the same set of variables can be used in the selection and structural equations, and both equations would be correctly identified. Regardless, there are some variables that drive the merger decision without affecting CARs and vice versa. The isolation of these variables in the appropriate model (selection or structural) provides a stronger basis for identifying the model. For example, prior to a merger announcement, investors estimate managerial motives for a merger using publicly available information. Accordingly, to predict candidacy we only use information that is publicly available prior to a merger announcement. We do not include information on the items of negotiations, merger terms, and merger fit in the selection model since investors do not have access to this information prior to the announcements. Conversely, we exclude information that is publicly available prior to a merger announcement from the model of CARs because in efficient markets, share prices should already reflect this information (e.g., acquirer size or performance). Accordingly, to evaluate merger announcement CARs, we use only information that becomes available at the merger announcement: items of negotiation, merger terms, fit between merger partners, and unanticipated merger motives. Finally, we use White's (1980) heteroscedasticity correction in the OLS regressions of bidder and target CARs by clustering on firm identity.

\subsection{Sample data}

The sample examined in this paper includes both merging and non-merging firms. The sample of public and private merging firms is compiled from the Security Data Company's (henceforth SDC) US Mergers and Acquisitions database. The sample includes those completed mergers announced between July 1, $1979^{5}$ and December 31, 2004. We focus only on mergers that transfer control rights from the target to the bidder firm. Intent to transfer control rights is characterized by two conditions: i) the bidder owns less than $50 \%$ of outstanding target shares prior to the merger, and ii) the bidder proposes to own more than $50 \%$ of outstanding target shares when and if the merger is completed. We use the SDC data items labeled as "menumain" and "formc" to identify those mergers that involve intent to transfer control rights. ${ }^{6}$

The sample of merging firms includes nonfinancial U.S.-based enterprises. We restrict the sample to U.S. firms due to data restrictions on foreign firms. We restrict the sample to nonfinancial firms because the regulatory environment requires a separate analysis for financial institutions. Finally, because share price information cannot be observed for non-public firms, at least one of the two firms involved in the second stage merger analysis must be publicly traded. The sample of non-merging firms is compiled from the CRSP-COMPUSTAT combined database. We apply the same sample selection criteria to the non-merging firms as we apply to the merging firms. That is, the non-merging firm sample includes only U.S.-based, nonfinancial firms.

\footnotetext{
${ }^{4}$ However, previous research has found that target shareholders almost always gain from a merger announcement.

${ }^{5}$ The SDC merger database starts in January 1977. We need two years of lagged data to construct some variables. Hence, the sample starts in 1979.

${ }^{6}$ The "menumain" data item in the SDC database classifies merger transactions into 12 categories: disclosed value, undisclosed value, leveraged buyouts, tender offers, spinoffs, recapitalizations, self-tenders, exchange offers, repurchases, SP, acquisition of remaining interest, and privatization. Based on SDC categories, we include only disclosed value, undisclosed value, leverage buyouts, and tender offers in our analysis. Then, the "formc" data item in the SDC database classifies merger deals into 10 categories: merger, acquisition, acquisition of majority interest, acquisition of partial interest, acquisition of remaining interest, acquisition of assets, acquisition of certain assets, recapitalization, buyback, and exchange offer. Based on SDC categories, we include only merger, acquisition, and acquisition of majority interest in our analysis.
} 
We use the annual industrial CRSP-COMPUSTAT database to compile financial statement data for the 26 year period from 1979 through 2004. For the merging and non-merging firms in the sample, we label a firm as a bidder, a target, or a nonmerging firm in that year. That is, based on SDC announcement dates for the merging firm sample, a firm in the CRSPCOMPUSTAT sample is identified as a bidder firm in a given year if it proposes at least one merger bid in the next financial statement release year, ${ }^{7}$ a firm is identified as a target firm if it receives at least one merger bid in the next year, and a firm is identified as a non-merging firm in a given year if it neither proposes nor receives a merger bid in the next year. ${ }^{8}$ Using the filters and classification described above, 2579 firms propose 6010 bids in 4964 firm years, 2575 firms solicit/receive 3043 bids in 2830 firm years, and 12,856 firms neither propose nor receive bids in 90,760 firm quarters. Therefore, the bidder subsample includes 4964 firm years, the target subsample includes 2830 firm years, and the non-merging subsample includes 90,760 firm years, for a sample total of 98,554 firm years.

\section{Predicting bidder and target candidacy}

In this section, we describe variables used to predict bidder and target candidacy and thus, management's motives for a merger. As stated above, we include only variables that represent information that is publicly available prior to a merger announcement. All balance sheet data is taken from the CRSP-COMPUSTAT database for each year over the sample period. To reduce the effect of outliers, we windsorize the variables at the 1st and 99th percentiles. We also verify the accuracy of remaining data which appear to be outliers. Table 1 summarizes the variables used in the model. The descriptive statistics for the variables are listed in Appendix A to the paper.

\subsection{Variables that measure management's motives to generate shareholder value}

Previous studies have found that a merger may increase shareholder value in four ways: i) by reallocating resources to withstand economic disturbances (Gort (1969), Mitchell and Mulherin (1996), Maksimovic and Phillips (2001), and Andrade et al. (2001)); ii) by achieving economies of scale and scope (Gort (1969), Palepu (1986), Ambrose and Megginson (1992), Moeller et al. (2004), and Fluck and Lynch (1999)); iii) by gaining access to additional sources of capital that allow the firm to grow (Fluck and Lynch (1999), Palepu (1986), Ambrose and Megginson (1992), Lang et al. (1989), Holmes and Schmitz (1995), Maksimovic and Phillips (2001), and Jovanovic and Rousseau (2002)); and iv) by exploiting discrepancies in valuation (Gort (1969)).

Mergers may be motivated by management's desire to withstand economic disturbances that may affect firm sales, profit, and value. Thus, larger economic disturbances experienced by a firm could be used to predict bidder and target merger candidacy. We adopt the Mitchell and Mulherin (1996) sales shock variable as our proxy for economic disturbances. That is, we define sales shock as the absolute value of the difference between the two-year median industry ${ }^{9}$ sales growth rate and the two-year median sales growth rate for all firms listed in our sample. To account for convexity in the sales shock variable, we include a second variable, the square of sales shock.

The desire to reduce costs through economies of scale and scope might also motivate mergers. Two measures of scale and scope are firm size and firm sales levels. If economies of scale or scope exist, firm size, changes in firm size, and changes in firm's sales could predict bidder and target firm merger candidacy (Gort (1969), Palepu (1986), Ambrose and Megginson (1992), and Moeller et al. (2004)). We use the log of total assets as the measure of firm size. We define change in size as the percentage change in the firm's total assets over the previous two years and sales growth as the percentage change in the firm's sales over the previous two years.

Models of economic disturbance and economies of scale and scope both suggest that barriers to entry and exit (due to economic conditions or size) could be used to predict bidder and target candidacy. Gort (1969) and Eckbo (1992) use a measure of concentration ratio as a proxy for barriers to entry. Specifically, Gort hypothesizes that the concentration ratio is a measure of both large firm dominance and the extent of barriers to entry. That is, if there is large firm dominance in an industry, the firms in that industry are more likely to engage in mergers. In the case of cross-industry mergers, mergers are a way for smaller firms to survive in industries that have large players. In the case of intra-industry mergers, mergers are an attempt to reduce competition. Accordingly, a high concentration ratio is associated with a higher likelihood of merger. ${ }^{10}$ We adopt this measure of barriers to entry and define concentration ratio as the ratio of sales of the largest four firms to total industry (using a three-digit SIC) sales.

Mergers may enable firms to gain access to additional sources of capital (Fluck and Lynch (1999), Palepu (1986), and Ambrose and Megginson (1992)) and thus, allow well managed firms to grow (Lang et al. (1989), Holmes and Schmitz (1995), Maksimovic

\footnotetext{
${ }^{7}$ A firm may propose or receive more than one bid in any one year. A firm that proposes and receives a merger bid in the next year will enter the sample as a bidder firm and a target firm.

${ }^{8}$ Some of the non-merging firms change the release dates of their financial statements. As a result, around the change in the release date, these firms have two sets of data (one set for the previous fiscal year date and one set for the new fiscal year date) in the same year. In these cases, we drop the double-counted firmyears.

${ }^{9}$ Industry firms include all firms with the same three-digit SIC code from our sample. If there are fewer than five firms in an industry, the two-digit SIC code is used.

${ }^{10}$ Eckbo et al (1990) find that bidder returns decrease in industry concentration and in the number of rival firms in the industry. If concentration is associated with a higher likelihood, and thus predictability, of a merger, this would explain the decrease in bidder merger returns.
} 
Table 1

Description of variables used to predict bidder and target firm merger candidacy. This table describes the variables used to predict bidder and target firm merger candidacy. The sample covers 26 years from 1979 through 2004. All data come from CRSP-COMPUSTAT database. Based on SDC announcement dates for the merging firm sample, a firm is identified as a bidder firm in a given year if it proposes at least one merger in the next financial statement release year, a firm is identified as a target firm if it receives at least one merger bid in the next year, and a firm is identified as a non-merging firm if it neither proposes nor receives a merger bid in the next year.

\begin{tabular}{|c|c|}
\hline Variable & Definition \\
\hline Sales shock & $\begin{array}{l}\text { The absolute value of the difference between the two-year median industry sales growth and the } \\
\text { two-year median sales growth for all firms in the sample. }\end{array}$ \\
\hline Sales shock squared & Square of sales shock \\
\hline Size & The log of total assets. \\
\hline Change in size & The percentage change in the book value of assets of the firm in the last two years. \\
\hline Sales growth & The change in the firm's net sales in the last two years. \\
\hline Concentration ratio & The ratio of sales of the largest four firms (in terms of sales) to total industry sales. \\
\hline Resource-growth-mismatch & $\begin{array}{l}\text { A dummy variable equal to one if i) sales growth for a firm in the last two years is less } \\
\text { than the industry median and long-term debt ratio is greater than the industry median, or ii) if sales } \\
\text { growth in the last two years is greater than the industry median and long-term debt ratio is less than } \\
\text { the industry median, and zero otherwise. }\end{array}$ \\
\hline Return on assets (ROA) & The ratio of net income before extraordinary (or nonrecurring) items to total assets. \\
\hline Share turnover & Ratio of the number of shares of stock traded for the firm to the total shares outstanding. \\
\hline Cash ratio & Ratio of cash to total assets. \\
\hline Previous mergers & Counts the number of times a firm proposes or receives a merger bid in the prior two years. \\
\hline Dormant period & The number of months since the last merger in the industry (industry is defined at the 3-digit SIC level). \\
\hline Price run-up & Percentage change in a firm's stock price in the prior two years. \\
\hline Information asymmetry & $\begin{array}{l}\text { Dummy variable equal to one if the market-to-book ratio is higher than the industry median and share } \\
\text { turnover is lower than to the industry median and zero otherwise. }\end{array}$ \\
\hline
\end{tabular}

and Phillips (2001), and Jovanovic and Rousseau (2002)). Following Palepu (1986) and Ambrose and Megginson (1992), we define resource-growth-mismatch as a dummy variable equal to one if $\mathrm{i}$ ) sales growth for a firm in the last two years is less than the industry median and the long-term debt ratio (ratio of book value of long-term debt to total assets) is greater than the industry median, or ii) if sales growth in the last two years is greater than the industry median and the long-term debt ratio is less than the industry median, and zero otherwise. The measure represents management motives to access new sources of capital. That is, this variable identifies firms with either growth opportunities but insufficient capital access, or with insufficient growth opportunities but capital access. Thus, larger resource-growth-mismatch experienced by a firm could be used to predict merger candidacy.

Further, bidder firms with superior management that acquire poorly managed target firms (and their underutilized capital) are more likely to employ post-merger assets more efficiently. A gauge of a well managed firm is profitability, which we measure as return on assets (ROA). ROA is calculated as the ratio of net income before extraordinary (or nonrecurring) items to total assets. A larger ROA for a firm may predict merger candidacy.

Gort (1969) predicts that discrepancies in valuation may prompt mergers. Gort measures discrepancies in firm valuation using low share turnover. We follow Gort and use share turnover as a proxy measure for discrepencies in opinion. Specifically, high share turnover, meaning more purchases, would indicate higher discrepencies in opinion. Following Gort, we expect that the higher a firm's share turnover, the more likely it is that the firm proposes and/or receives a merger bid. We define share turnover as the ratio of the number of shares of stock traded for the firm to the total shares outstanding and use this measure as a proxy for discrepancies in valuation.

\subsection{Variables that measure management's motives to generate opportunistic benefits}

Harford (1999) shows that firms with excess cash are more likely to make acquisitions and their acquisitions are more likely to be value decreasing. Harford et al. (2008) also find that entrenched managers primarily spend their cash on acquisitions. Hence, to exploit opportunistic benefits, firms with large cash reserves would be more likely to propose a merger and less likely to receive a merger bid. We define cash ratio as the ratio of cash and marketable securities to total assets.

In the pursuit of opportunistic benefits, we also explore the possibility that firm managers may be motivated to propose multiple mergers to build empires. Indeed, research has found that individual firms with a history of mergers are more likely to propose and receive additional merger bids (Schipper and Thompson (1983), Malatesta and Thomson (1985), Asquith et al. (1983), Loderer and Martin (1990), Holmes and Schmit (1995), Fuller et al. (2002), and Ismail (2005)). However, Aktas et al. (2009) find that rather than hubris, CEOs of frequent acquirers are on a learning curve: they often start with small, lower-risk deals and build capabilities in deal making. As acquirer CEOs are learning, they improve their target selection and integration processing abilities from deal to deal. This learning process has consequences for the bidding such that abnormal returns decrease from deal to deal. Accordingly, we track the merger record of the bidder firms to construct a variable, previous mergers, that counts the number of times a firm proposes or receives a merger bid in the prior two years. A higher value for previous mergers could be used to predict bidder candidacy as each additional bid may be part of an overall acquisition program. Similarly, prior literature has documented that many acquirers are subsequently taken over themselves, especially those that engaged in value destroying 
acquisitions. This suggests that past bidding behavior may increase the likelihood of being a target. ${ }^{11}$ Separately, firms that have already received a merger bid are more likely to look for a subsequent bid. Thus, for target firms we also track previous mergers in the prior two years. A higher value for previous bids could be used to predict target candidacy.

Song and Walkling $(2000,2008)$ find evidence of anticipation and transfer of information throughout an industry at the announcement of initial bidding activity. Specifically, they find that abnormal returns of bidding firms are significantly positively related to the length of time between bid announcements in an industry. Further, at the time of an industry's initial announcement, rivals that will bid in the future experience significant price adjustments in comparison to non-bidding rivals. Thus, firm managers may be motivated to merge simply to partake in the merger wave and not necessarily to build shareholder value. We define dormant period as the number of months since the last merger in the industry. We again define industry by using the three-digit SIC code as listed in the CRSP-COMPUSTAT database. We calculate dormant period for every industry in our merging firm sample. A low value for dormant period would indicate greater merger intensity in the industry and may be used to predict merger candidacy.

\subsection{Variables that measure management's motives to generate shareholder value and generate opportunistic benefits}

Myers and Majluf (1984) show that mispricing in share prices may alter investment decisions of the mispriced firm's management. Managers, as decision makers, have private information about the firm. Indeed, Eckbo et al. (1990) find that managers of bidders, but not targets, have valuable private information about the potential synergies from proposed mergers. Two opposing views investigate whether managers utilize their information advantage to serve shareholders or to protect opportunistic benefits. On the one hand, managers, who believe their stock is overvalued, may try to generate long run value for pre-merger shareholders at the expense of post-merger shareholders (Hansen (1987), Schwert (1996), and Betton et al. (2009)). Uncertainty about private values enables managers to hide their true goals. Information asymmetry models (such as Rhoades-Kropf and Viswanathan (2004)) find that for a target firm's management to agree to a merger bid proposed by an overvalued bidder, they must be fooled into thinking that the bidder firm is less overvalued than it is. On the other hand, overvaluation may intensify incentive conflicts between the firm's managers and shareholders. That is, managers may be tempted to destroy shareholder value using mergers financed with overvalued equity in an attempt to protect opportunistic benefits at the expense of both pre- and post-merger shareholders (Jensen (2005)).

We use two variables, price run-up and information asymmetry, to measure management's motives to exploit its information advantage when markets misprice the value of a firm. We define price run-up as the change in a firm's stock price in the two years prior to a given quarter. Stock price data are taken from the CRSP-COMPUSTAT database. Information asymmetry is a dummy variable that measures both overvaluation and opaqueness in share prices. This variable takes a value one if a firm's stock price is overvalued (measured as a market-to-book value [equals (the closing price of the firm's common stock $\times$ the number of common shares outstanding)/the book value of stockholder's equity at the end of each year as listed in CRSP-COMPUSTAT database] that is greater than the industry median) and opaque (the firm's share turnover (as defined above) is lower than its industry median), and zero otherwise. Rhodes-Kropf and Viswanathan (2004) find that overvalued and opaque firms are more likely to make merger bids to exploit the overvaluation in their shares. High price run-up and high information asymmetry provides bidder firm management with an environment that allows for this.

\subsection{Results of merger candidacy models}

We run 26 multinomial logit regressions (one for each year from 1979 through 2004) on the proxies for merger motives to estimate investor anticipations about bidder candidacy (Eq. 1). Based on SDC announcement dates for the merging firm sample, a firm is identified as a bidder firm in a given year if it proposes at least one merger bid in the next financial statement release year, a firm is identified as a target firm if it receives at least one merger bid in the next year, and a firm is identified as a non-merging firm if it neither proposes nor receives a merger bid in the next year. Thus, the indicator is set equal to 0 if the firm proposes a bid in the next year, to 1 if the firm receives a bid in the next year, and to 2 if it neither proposes nor receives a bid. Thus, following Eq. (1), we run the following:

$$
\begin{aligned}
M_{j}= & (\text { sales schock })_{\mathrm{j}} \times \gamma_{\mathrm{j}}^{(\text {(sales shock })}+(\text { square of sales shock })_{\mathrm{j}} \times \gamma_{\mathrm{j}}^{(\text {square of sales schock })}+(\text { size })_{\mathrm{j}} \times \gamma_{\mathrm{j}}^{(\text {(size })} \\
& +(\text { change in size })_{\mathrm{j}} \times \gamma_{\mathrm{j}}^{(\text {(change in size })}+(\text { sales growth })_{\mathrm{j}} \times \gamma_{\mathrm{j}}^{(\text {sales growth })}+(\text { concentration ratio })_{\mathrm{j}} \times \gamma_{\mathrm{j}}^{(\text {(concentration ratio })} \\
& +(\text { (resource-growth-mismatch })_{\mathrm{j}} \times \gamma_{\mathrm{j}}^{(\text {(resource growth-mismatch })}+(\mathrm{ROA})_{\mathrm{j}} \times \gamma_{\mathrm{j}}^{(\text {ROA })}+(\text { share turnover })_{\mathrm{j}} \times \gamma_{\mathrm{j}}^{(\text {(share turnover })} \\
& +(\text { cash ratio })_{\mathrm{j}} \times \gamma_{\mathrm{j}}^{(\text {(cash ratio })}+(\text { previous bids })_{\mathrm{j}} \times \gamma_{\mathrm{j}}^{(\text {(previous bids })}+(\text { dormant period })_{\mathrm{j}} \times \gamma_{\mathrm{j}}^{(\text {(dormant period })} \\
& +(\text { price run-up })_{\mathrm{j}} \times \gamma_{\mathrm{j}}^{\text {(price run-up })}+(\text { information asymmetry })_{\mathrm{j}} \times \gamma_{\mathrm{j}}^{(\text {(information asymmetry })}+\varepsilon_{\mathrm{j}} \\
& \text { for } \mathrm{j}=\text { bidder, target, non-merging firms }
\end{aligned}
$$

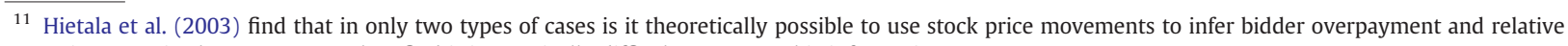
synergies. Even in these two cases they find it is practically difficult to extract this information.
} 
We report the results of regression Eq. (6) in Table 2. Panels A and B report the mean, standard deviation, 25th, 50th, and 75th percentile values of the marginal coefficient estimates for bidder and target firms, respectively. Marginal probabilities are estimated at the median values for the continuous variables and at zero for the information asymmetry and resource-growth-mismatch dummy variables. The estimates are the derivatives of the probability to propose and receive a merger bid with respect to a particular exogenous variable. Panel $\mathrm{C}$ reports the goodness-of-fit diagnostics. The last column in Table 2 reports the t-statistic for the test of the null hypothesis of no predictability in bidder and target merger candidacy, which would be confirmed only if all regression slopes differ insignificantly from zero.

Table 2 indicates that a mix of motives prompts management to propose and receive merger bids. From Panel A of Table 2, variables that represent bidder management's motives to generate shareholder value (large asset size $(t=9.39)$, high asset growth $(t=1.99)$, high concentration ratio $(t=2.85)$, high ROA $(t=3.63)$, and high share turnover $(t=8.71)$, to generate opportunistic benefits (high previous mergers $(t=9.99)$ and short dormant period $(t=-3.81$ ), and to do both (high price run-up $(t=5.63))$ predict bidder candidacy. From Panel B of Table 2, proxies that represent target firm management's motives to generate shareholder value (high sales shock $(t=1.95)$, high ROA $(t=3.52)$, high share turnover $(t=6.64)$, small asset size $(t=-2.98)$, low asset and sales growth $(t=-3.43$ and -2.73 , respectively), to generate opportunistic benefits (low cash ratio ( $t=-2.04$ ) and short dormant period $(\mathrm{t}=-4.18)$ ), and to do both (low price run-up $(\mathrm{t}=-2.53$ ) and low information asymmetry ( $\mathrm{t}=$ -3.65)) predict target candidacy. ${ }^{12}$ Results indicate that markets can predict bidder and target candidacy.

Table 3 further investigates the predictive power of the bidder and target candidacy models. Panels A and B report summary statistics on the probability to propose and receive a bid, respectively, in the bidder, target, and non-merging firms subsamples as estimated by the candidacy model. Panel C reports summary statistics on the $\mathrm{X}^{2}$ statistic of the likelihood-ratio test and pseudo $\mathrm{R}^{2}$. In our sample, the fraction of bidder-years is 5.04\% (4964 of the sample total 98,554 firm years) and the fraction of target-years is $2.87 \%$ ( 2830 of the sample total). Panel A in Table 3 reports that the average probability of proposing a bid is $12.12 \%$ for bidders, $6.78 \%$ for targets, and $4.60 \%$ for non-merging firms. The average probability of receiving a bid is $4.50 \%$ for targets, 3.94 for bidders, and $2.76 \%$ for non-merging firms, respectively. Thus, the candidacy models correctly estimate that bidders are more likely to propose bids than nonbidders and that targets are more likely to receive bids than nontargets. Investors do not do as good a job in predicting target candidates as they do in predicting bidder candidates. Panel $\mathrm{C}$ of Table 3 reports the average $\mathrm{R}^{2}$ in the crosssectional regressions as $8.10 \%$. The null hypothesis that the model has no explanatory power is rejected in all 26 regressions. The overall fit of the logit models is modest but similar to the previous literature (e.g., Ambrose and Megginson (1992) and Cremers et al. (2009)). For example, Cremers et al.'s logit models produce pseudo $\mathrm{R}^{2}$ values of $3.13 \%$ and $9.27 \%$ for their samples of completed takeovers.

\section{Stock market responses to merger announcements}

Next we examine whether predictability in merger candidacy affects stock price responses to merger announcements. Specifically, we estimate different specifications of regression Eqs. (4) (for bidder firms) and (5) (for target firms). In all specifications, the dependent variable is the 3-day CAR. ${ }^{13}$ Abnormal returns are calculated as the difference between observed and "normal" returns. We use the market-model to estimate "normal returns" for the merging firms. ${ }^{14}$ In these regressions, we control for information that is released at the merger announcement such as features of the contract (e.g., all equity, deal value, and relative size), the economic fit between merger partners (e.g., same industry and same state), and the relative bargaining power of the merger partners (e.g., anti-takeover defense, unwelcoming attitude, and target bankrupt). These data are collected from the SDC database. The variables are discussed below and are summarized in Table 4. To reduce the effect of outliers (very large bidders or targets), we windsorize the observations at the 1st and 99th percentiles based on the relative value variable. Descriptive statistics for these regression variables are reported Appendix B to the paper. Table 5 reports regression results for bidder firms and Table 6 reports results for target firms. The regressions differ in the combination of control variables included. In 212 of the deals, there is at least one more merger announcement by either the bidder or the target on the same date. We exclude these deals from the sample since it is not possible to uniquely attribute the abnormal returns observed around the announcement to a specific deal. Finally, the sample of merger deals analyzed includes 5740 proposed bids and 2963 solicited/received bids.

\subsection{Regressions of bidder cumulative abnormal returns}

Table 5 reports regression results of the 3-day CAR for bidder firms at a merger announcement. The first four regressions include the surprise instrument and variables that control for the method of financing the merger, that proxy for the economic fit, and that examine bargaining power of bidders versus targets involved in the merger. The fifth regression includes all explanatory variables except the surprise instrument so as to benchmark the results against a single-equation model.

\footnotetext{
12 The results are consistent in sign and magnitude with those of previous studies, e.g., Moeller et al. (2004) for asset size and asset growth, Asquith et al. (1983) and many others for ROA, Song and Walkling $(2000,2008)$ for previous mergers and dormant period, and Asquith et al. (1983) for price run-up.

${ }_{13}$ We also examine alternative event-windows such as 7-day, 11-day, and 15-day to calculate abnormal returns. The results remain qualitatively unchanged.

14 Market-model estimation starts 256 days prior to the merger announcement and ends 30 days prior to the announcement. We require that each firm have at least 30 observations for the market-model estimation. We use EVENTUS to calculate cumulative abnormal returns by summing daily abnormal returns over the three-day event window. We use the equally-weighted CRSP index as the market proxy. We also examine alternative models that use the value-weighted CRSP index as the market proxy. The results remain qualitatively unchanged.
} 
Table 2

Multinomial logit regressions of bidder and target candidacy. This table reports results of 26 cross-sectional multinomial logit regressions. Based on SDC announcement dates for the merging firm sample, a firm is identified as a bidder firm in a given year if it proposes at least one merger in the next financial statement release year, as a target firm in a given year if it receives at least one bid in the next year, as a non-merging firm if it neither proposes nor receives a bid in the next year. The indicator is set equal to 0 if the firm proposes a bid in the next year, to 1 if it receives a bid and 2 otherwise. Panels A and B report the mean, standard deviation, 25th, 50th, and 75th percentile values of the marginal coefficient estimates for bidder and target candidacy, respectively. Marginal probabilities are estimated at the median values for the continuous variables and at zero for the high information asymmetry and resource-growth-mismatch indicator variables. Last column in Panel A and B reports the t-statistic for the test of the null hypothesis that the mean of the coefficient is equal to 0 . Panel C reports pseudo $\mathrm{R}^{2}$. Marginal probability estimates and pseudo $\mathrm{R}^{2}$ are in percent.

\begin{tabular}{|c|c|c|c|c|c|c|}
\hline & Mean & Standard Deviation & 25th percentile & 50th percentile & 75th percentile & t-statistic \\
\hline \multicolumn{7}{|c|}{ Panel A - summary statistics for marginal-probability estimates, bidder firms } \\
\hline Sales shock & 0.20 & 5.38 & -2.54 & 0.87 & 2.86 & 0.19 \\
\hline Sales shock squared & -0.23 & 13.35 & -4.05 & -0.75 & 2.21 & -0.09 \\
\hline Size & 0.50 & 0.27 & 0.31 & 0.46 & 0.69 & 9.39 \\
\hline Change in size & 0.14 & 0.35 & -0.02 & 0.02 & 0.31 & 1.99 \\
\hline Sales growth & 0.02 & 0.32 & -0.05 & 0.07 & 0.18 & 0.24 \\
\hline Concentration ratio & 1.24 & 2.22 & -0.31 & 0.82 & 1.98 & 2.85 \\
\hline Resource-growth-mismatch & -0.11 & 0.43 & -0.22 & 0.01 & 0.16 & -1.29 \\
\hline $\mathrm{ROA}$ & 3.83 & 5.39 & 0.76 & 2.11 & 4.19 & 3.63 \\
\hline Share turnover & 0.67 & 0.39 & 0.53 & 0.71 & 0.94 & 8.71 \\
\hline Cash ratio & 0.90 & 6.06 & 0.92 & 2.41 & 3.63 & 0.76 \\
\hline Previous mergers & 2.37 & 1.21 & 1.62 & 2.18 & 3.30 & 9.99 \\
\hline Dormant period & -0.03 & 0.04 & -0.05 & -0.02 & 0.00 & -3.81 \\
\hline Price run-up & 0.30 & 0.27 & 0.15 & 0.28 & 0.48 & 5.63 \\
\hline Information asymmetry & -0.07 & 0.85 & -0.45 & -0.04 & 0.58 & -0.44 \\
\hline \multicolumn{7}{|c|}{ Panel B - summary statistics for marginal-probability estimates, target firms } \\
\hline Sales shock & 1.93 & 5.05 & -1.72 & 1.26 & 5.80 & 1.95 \\
\hline Sales shock squared & -4.77 & 15.98 & -8.01 & -1.31 & 2.76 & -1.52 \\
\hline Size & -0.11 & 0.19 & -0.20 & -0.10 & 0.00 & -2.98 \\
\hline Change in size & -0.31 & 0.46 & -0.74 & -0.26 & 0.09 & -3.43 \\
\hline Sales growth & -0.29 & 0.54 & -0.39 & -0.11 & 0.02 & -2.73 \\
\hline Concentration ratio & 0.15 & 1.68 & -0.25 & 0.15 & 1.15 & 0.46 \\
\hline Resource-growth-mismatch & 0.08 & 0.52 & -0.26 & -0.02 & 0.30 & 0.82 \\
\hline ROA & 1.38 & 2.00 & 0.12 & 0.57 & 1.87 & 3.52 \\
\hline Share turnover & 0.86 & 0.66 & 0.38 & 0.60 & 1.24 & 6.64 \\
\hline Cash ratio & -1.69 & 4.23 & -4.41 & -1.55 & 1.19 & -2.04 \\
\hline Previous mergers & -1.05 & 11.69 & 0.82 & 1.07 & 2.07 & -0.46 \\
\hline Dormant period & -0.06 & 0.07 & -0.08 & -0.04 & -0.01 & -4.18 \\
\hline Price run-up & -0.15 & 0.30 & -0.41 & -0.14 & 0.10 & -2.53 \\
\hline Information asymmetry & -0.55 & 0.77 & -1.00 & -0.47 & -0.04 & -3.65 \\
\hline \multicolumn{7}{|c|}{ Panel C - goodness-of-fit diagnostics } \\
\hline Pseudo $\mathrm{R}^{2}$ & 8.10 & 2.05 & 7.29 & 7.62 & 8.53 & \\
\hline
\end{tabular}

The surprise instrument allows us to measure how investor anticipations influence stock market responses to merger announcements. The greater the surprise in a merger announcement, the greater is the information revealed about unanticipated merger motives and the larger is the surprise instrument. Hence, the surprise instrument is intuitively a measure of the extent to

Table 3

Goodness-of-fit diagnostics for models of candidacy. Panel A reports the mean, standard deviation, minimum, 25th, 50th, 75th percentile, and maximum values of the probability to propose a bid in the bidder, target and non-merging firms subsamples as estimated by the candidacy model. Panel B reports the mean, standard deviation, minimum, 25th, 50th, 75th percentile, and maximum values of the probability to receive a bid in the bidder, target and non-merging firms subsamples as estimated by the candidacy model. Panel C reports the mean, standard deviation, minimum, 25th, 50th, 75 th percentile, and maximum values for the $\mathrm{X}^{2}$ statistic of the likelihood-ratio test and pseudo $\mathrm{R}^{2}$. Predicted probabilities and Pseudo $\mathrm{R}^{2}$ are in percent.

\begin{tabular}{|c|c|c|c|c|c|c|c|c|}
\hline & Mean & Standard deviation & Minimum & 25th percentile & 50th percentile & 75th percentile & Maximum & $\mathrm{N}$ \\
\hline \multicolumn{9}{|c|}{ Panel A - distribution of probability of bidding by bidder, target, and non-merging firms } \\
\hline Bidder firms & 12.12 & 14.12 & 0.08 & 4.37 & 7.34 & 13.31 & 99.95 & 4964 \\
\hline Target firms & 6.78 & 8.27 & 0.00 & 2.79 & 4.53 & 7.65 & 92.86 & 2830 \\
\hline Non-merger firms & 4.60 & 4.95 & 0.00 & 1.96 & 3.47 & 5.66 & 98.79 & 90,760 \\
\hline \multicolumn{9}{|c|}{ Panel B - distribution of probability of receiving bids by bidder, target, and non-merging firms } \\
\hline Bidder firms & 3.94 & 3.00 & 0.00 & 2.02 & 3.28 & 5.03 & 51.31 & 4964 \\
\hline Target firms & 4.50 & 3.40 & 0.11 & 2.63 & 3.77 & 5.48 & 54.29 & 2830 \\
\hline Non-merger firms & 2.76 & 2.05 & 0.00 & 1.36 & 2.40 & 3.71 & 46.15 & 90,760 \\
\hline \multicolumn{9}{|c|}{ Panel C - goodness-of-fit diagnostics } \\
\hline Pseudo R2 & 8.10 & 2.05 & 4.54 & 7.29 & 7.62 & 8.53 & 16.15 & 26 \\
\hline $\mathrm{X}^{2}$ statistic & 185.84 & 85.79 & 62.18 & 124.66 & 159.13 & 235.26 & 356.84 & 26 \\
\hline
\end{tabular}




\section{Table 4}

Description of variables used to explain merger announcement cumulative abnormal returns. This table describes the variables used to examine whether predictability in merger candidacy affects stock price responses to merger announcements. The sample covers 26 years from 1979 through 2004 . The variables are compiled using the SDC database. Based on SDC announcement dates for the merging firm sample, a firm is identified as a bidder firm in a given quarter if it proposes at least one merger in the next financial statement release year and a firm is identified as a target firm if it receives at least one merger bid in the next year.

\begin{tabular}{ll}
\hline Variable & Definition \\
\hline $\begin{array}{l}\text { All-equity indicator } \\
\text { Deal value } \\
\text { Relative value }\end{array}$ & $\begin{array}{l}\text { Dummy variable equal to one if the merger is financed only with equity of the bidder firm and zero otherwise. } \\
\text { The announced value of merger, in billions of dollars. } \\
\text { The ratio of the value of the merger to the market value of the bidder's (target's) common stock at the quarter end } \\
\text { prior to the merger announcement. }\end{array}$ \\
$\begin{array}{l}\text { Dummy variable equal to one if the merging firms are in the same industry, and zero otherwise. } \\
\text { Same state }\end{array}$ & $\begin{array}{l}\text { Dummy variable equal to one if the main operations of bidder and target firms are in the same state, } \\
\text { and zero otherwise. }\end{array}$ \\
Anti-takeover defense & $\begin{array}{l}\text { and zero otherwise. } \\
\text { Dummy variable equal to one if the target firm management's initial recommendation is negative or the target firm } \\
\text { did not solicit the bid, and zero otherwise. } \\
\text { Dummy variable equal to one if the target firm is in bankruptcy proceedings at the time of the merger announcement, } \\
\text { and zero otherwise. } \\
\text { Dummy variable equal to one if the counterparty (target for bidders and bidder for targets) is a private firm at the } \\
\text { time of the merger announcement and zero otherwise. }\end{array}$ \\
\end{tabular}

which a merger announcement surprises the market. As mentioned above, we generate an indicator variable that takes the value one when CAR is positive and zero when CAR is negative. We then interact this variable with the surprise instrument in bidder and target regressions. Thus, the coefficient on the surprise instrument measures the surprise reaction to negative CAR deals. The coefficient for the surprise instrument for positive deals is equal to coefficient of the surprise instrument plus the coefficient of the interaction variable.

The coefficients on the surprise instrument are negative and statistically significant in all regressions in Table 5 (t-statistics range from 4.44 to 5.40). Further, the coefficients on the interaction are positive and highly significant (t-statistics range from 15.17 to 16.70). The coefficients on the surprise instrument for positive deals (the sum of the two coefficients) turn out to be positive and significant. This finding strongly supports the hypothesis that the magnitude of the CARs is affected by whether the merger announcement is a surprise or not. For negative CAR deals, the surprise is a bad surprise and as the surprise instrument increases (i.e., the surprise increases), CAR decreases and becomes even more negative (the coefficient is negative). For positive CAR deals, the surprise is a good surprise and as the surprise instrument increases (i.e., the surprise increases), CAR increases and becomes even more positive (the sum of coefficient and interaction is positive). Thus, the more surprised the market is about a merger deal, the greater is the impact of the announcement on bidder stock prices.

The all-equity dummy variable identifies the method of payment used in a merger. We set this variable equal to one if the merger is financed only with equity of the bidder firm and zero otherwise. Myers and Majluf's (1984) pecking-order hypothesis states that markets assess a firm as overvalued when equity is used to finance investment projects. Accordingly, we expect and find that all-equity financed mergers result in lower abnormal returns to bidder shareholders. ${ }^{15}$

Asquith et al. (1983) document that the larger the size of a target firm relative to the bidder firm in a merger, the greater are bidder and target cumulative returns at a merger announcement. Further, Moeller et al. (2005) find that mergers whose values exceed $\$ 1$ billion erode bidder shareholder value by $\$ 7.38$ per $\$ 100$ invested. Accordingly, we use two variables, deal value and relative size, to represent the absolute and relative size of the mergers. We define deal value as the announced value of a merger in billions of dollars and relative size as the ratio of the deal value to the market value of a bidder's (or target in Table 6) common stock at the year-end prior to a merger announcement. ${ }^{16}$ For bidder firms, the coefficient on deal value is negative and significant in all regressions. As in Moeller et al., the larger the absolute size of the deal, the greater is the erosion in bidder shareholder value at a merger announcement. Confirming Asquith et al., the larger the deal value relative to bidder size, the greater the positive impact of the announcement: the coefficients on relative size are positive but significant in only one of the three regressions.

Economic fit between bidder and target firms determines how much total shareholder value a merger might generate. Two variables are examined: whether merging firms operate in the same industry and whether they are located in the same state. Same industry is a dummy variable equal to one if the merging firms are in the same industry (using threedigit SIC codes) and zero otherwise. Similar to Campa and Kedia (2002) and Villalonga (2004), this variable measures the extent to which the merger is focus-increasing and focus- decreasing (or diversifying) and, therefore, the extent to which assets-in-place of the stand alone firms complement and/or substitute for each other. Geographic proximity may affect

\footnotetext{
15 The method of financing the merger is taken from the SDC database.

${ }^{16}$ Deal values are from the SDC database. Market value of common stock is the number of shares of common stock outstanding times the closing price of common stock and is taken from the CRSP-COMPUSTAT database.
} 
Table 5

Regressions of bidder CARs. This table reports results of regressions examining whether predictability in merger candidacy affects bidder stock price responses to merger announcements. Based on SDC announcement dates for the merging firm sample, a firm is identified as a bidder firm in a given year if it proposes at least one merger in the next financial statement release year. The dependent variable is the 3-day bidder cumulative abnormal returns. t-statistics based on the Huber/ White/Sandwich estimator of variance are reported in brackets. Coefficient estimates and $\mathrm{R}^{2}$ are in percent.

\begin{tabular}{|c|c|c|c|c|c|}
\hline & Regression 1 & Regression 2 & Regression 3 & Regression 4 & Regression 5 \\
\hline \multirow[t]{2}{*}{ Surprise instrument } & -1.93 & -1.94 & -1.69 & -1.70 & \\
\hline & {$[5.35]^{\mathrm{a}}$} & {$[5.40]^{\mathrm{a}}$} & {$[4.44]^{\mathrm{a}}$} & {$[4.46]^{\mathrm{a}}$} & \\
\hline \multirow[t]{2}{*}{ Surprise instrument interaction } & 6.05 & 6.06 & 6.08 & 6.09 & \\
\hline & {$[15.17]^{\mathrm{a}}$} & {$[15.18]^{\mathrm{a}}$} & {$[16.70]^{\mathrm{a}}$} & {$[16.70]^{\mathrm{a}}$} & \\
\hline \multirow[t]{2}{*}{ All-equity indicator } & -0.95 & -0.96 & -0.57 & -0.59 & -1.18 \\
\hline & {$[2.96]^{\mathrm{a}}$} & {$[2.95]^{\mathrm{a}}$} & {$[1.86]^{\mathrm{c}}$} & {$[1.89]^{\mathrm{c}}$} & {$[3.32]^{\mathrm{a}}$} \\
\hline \multirow[t]{2}{*}{ Deal value } & & & -0.17 & -0.16 & -0.23 \\
\hline & & & {$[4.81]^{\mathrm{a}}$} & {$[4.75]^{\mathrm{a}}$} & {$[4.48]^{\mathrm{a}}$} \\
\hline \multirow[t]{2}{*}{ Relative size } & & & 0.14 & 0.14 & 0.81 \\
\hline & & & [0.32] & {$[0.32]$} & {$[1.70]^{\mathrm{c}}$} \\
\hline \multirow[t]{2}{*}{ Same industry } & & -0.53 & & -0.24 & -0.05 \\
\hline & & {$[2.24]^{\mathrm{b}}$} & & {$[0.90]$} & {$[0.17]$} \\
\hline \multirow[t]{2}{*}{ Same state } & & 0.81 & & 0.48 & 0.42 \\
\hline & & {$[2.15]^{\mathrm{b}}$} & & [1.62] & [1.22] \\
\hline \multirow[t]{2}{*}{ Anti-takeover defense } & & & -1.23 & -1.20 & -0.66 \\
\hline & & & [1.22] & [1.19] & [0.55] \\
\hline \multirow[t]{2}{*}{ Unwelcoming attitude } & & & 0.83 & -0.85 & -0.14 \\
\hline & & & {$[1.78]^{\mathrm{c}}$} & {$[1.81]^{\mathrm{c}}$} & {$[0.23]$} \\
\hline \multirow[t]{2}{*}{ Target bankrupt } & & & 1.05 & 1.12 & 2.80 \\
\hline & & & [0.79] & {$[0.84]$} & {$[1.40]$} \\
\hline \multirow[t]{2}{*}{ Target status } & & & 1.30 & 1.29 & 2.15 \\
\hline & & & {$[5.34]^{\mathrm{a}}$} & {$[5.30]^{\mathrm{a}}$} & {$[7.28]^{\mathrm{a}}$} \\
\hline \multirow[t]{2}{*}{ Constant } & -4.44 & -4.62 & -5.47 & -5.60 & -2.19 \\
\hline & {$[2.06]^{\mathrm{b}}$} & {$[2.14]^{\mathrm{b}}$} & {$[2.19]^{\mathrm{b}}$} & {$[2.24]^{\mathrm{b}}$} & {$[0.84]$} \\
\hline Observations & 4789 & 4789 & 3481 & 3481 & 3481 \\
\hline Adjusted-R ${ }^{2}$ & 22.18 & 22.34 & 30.11 & 30.15 & 3.99 \\
\hline
\end{tabular}

a Significant at $1 \%$

b Significant at $10 \%$.

c Significant at $5 \%$.

the economic fit of the merging firms in two ways. First, firms that are closely situated may have similar corporate cultures, which in turn may affect the total shareholder value that a merger generates (Chakrabarti (2005)). Second, local deals may work to the advantage of bidder shareholders because proximity may mean that bidder management has superior information about the target than it would if the target firm was located further away (Kedia et al. (2005)). We define same state as a dummy variable equal to one if the main operations of bidder and target firms are in the same state and zero otherwise. Table 5 reports that the coefficients on these variables are significant (at 5\%) in explaining bidder CARs in Regression 2 and are insignificant in the other regressions. Thus, economic fit does appear to have a significant influence on bidder returns.

At a merger announcement, once the merger partners are known, the relative bargaining power of bidder and target firms is revealed. Relative bargaining power determines how the total value associated with a merger is shared between bidder and target firm shareholders. We use four variables to measure the relative bargaining power of bidders and targets: whether the target employs anti-takeover defenses (e.g., poison pills, lock-ups, greenmail, and white knights) to discourage a takeover attempt, whether the target management initially resists the merger, whether the target is in bankruptcy proceedings, and whether the counterparty is a private firm or not. Anti-takeover defenses strengthen target management's ability to resist takeovers and to increase the bargaining power of target management (Ambrose and Megginson (1992)). Further, when the target CEO gives an initial negative recommendation about the merger to the target firm's board the bargaining power of the target is strengthened since the bidder would likely have to increase its bid to overcome the initial resistance (Jennings and Mazzeo (1993)). Target bargaining power varies inversely with the need of target shareholders to sell the firm. The extreme case is shareholders of bankrupt (target) firms that are in dire need of help. Thus, bankruptcy proceedings would weaken the target's bargaining power. Anti-takeover defenses, unwelcoming attitude, and target bankrupt are dummy variables that control for the presence of anti-takeover defenses, for differences in the reception of merger proposals, and for the need to sell when in bankruptcy, respectively. ${ }^{17}$ Table 4 reports that none of these variables is consistently significant in explaining bidder announcement period CARs.

\footnotetext{
17 Information on these variables was obtained from the SDC database.
} 
Table 6

Regressions of target CARs. This table reports results of regressions examining whether predictability in merger candidacy affects target stock price responses to merger announcements. Based on SDC announcement dates for the merging firm sample, a firm is identified as a target firm in a given year if it receives at least one merger bid in the next financial statement release year. The dependent variable is the 3-day target cumulative abnormal returns. t-statistics based on the Huber/ White/Sandwich estimator of variance are reported in brackets. Coefficient estimates and $\mathrm{R}^{2}$ are in percent.

\begin{tabular}{|c|c|c|c|c|c|}
\hline & Regression 1 & Regression 2 & Regression 3 & Regression 4 & Regression 5 \\
\hline \multirow[t]{2}{*}{ Surprise instrument } & -10.08 & -10.08 & -9.25 & -9.26 & \\
\hline & {$[11.51]^{\mathrm{a}}$} & {$[11.50]^{\mathrm{a}}$} & {$[10.48]^{\mathrm{a}}$} & {$[10.47]^{\mathrm{a}}$} & \\
\hline \multirow[t]{2}{*}{ Surprise instrument interaction } & 11.00 & 11.00 & 10.13 & 10.14 & \\
\hline & {$[14.54]^{\mathrm{a}}$} & {$[14.55]^{\mathrm{a}}$} & {$[12.78]^{\mathrm{a}}$} & {$[12.77]^{\mathrm{a}}$} & \\
\hline \multirow[t]{2}{*}{ All-equity indicator } & -4.82 & -4.73 & -4.97 & -4.89 & -6.27 \\
\hline & {$[4.29]^{\mathrm{a}}$} & {$[4.25]^{\mathrm{a}}$} & {$[4.33]^{\mathrm{a}}$} & {$[4.28]^{\mathrm{a}}$} & {$[5.11]^{\mathrm{a}}$} \\
\hline \multirow[t]{2}{*}{ Deal value } & & & -0.10 & -0.11 & -0.10 \\
\hline & & & [1.49] & {$[1.51]$} & [1.29] \\
\hline \multirow[t]{2}{*}{ Relative size } & & & 4.75 & 4.74 & 5.59 \\
\hline & & & {$[6.14]^{\mathrm{a}}$} & {$[6.12]^{\mathrm{a}}$} & {$[6.86]^{\mathrm{a}}$} \\
\hline \multirow[t]{2}{*}{ Same industry } & & 0.51 & & 0.19 & -0.26 \\
\hline & & {$[0.48]$} & & [0.18] & {$[0.23]$} \\
\hline \multirow[t]{2}{*}{ Same state } & & -1.34 & & -1.12 & -1.08 \\
\hline & & {$[1.24]$} & & [1.10] & {$[0.98]$} \\
\hline \multirow[t]{2}{*}{ Anti-takeover defense } & & & 4.95 & 4.89 & 5.34 \\
\hline & & & [1.53] & [1.51] & [1.64] \\
\hline \multirow[t]{2}{*}{ Unwelcoming attitude } & & -0.67 & -0.67 & -0.72 & 1.25 \\
\hline & & & [0.47] & {$[0.51]$} & {$[0.84]$} \\
\hline \multirow[t]{2}{*}{ Target bankrupt } & & & 15.59 & 15.50 & 18.63 \\
\hline & & & [1.14] & [1.14] & [1.34] \\
\hline \multirow[t]{2}{*}{ Bidder status } & & & -4.34 & -4.26 & -4.69 \\
\hline & & & {$[2.79]^{\mathrm{a}}$} & {$[2.75]^{\mathrm{a}}$} & {$[2.77]^{\mathrm{a}}$} \\
\hline \multirow[t]{2}{*}{ Constant } & 11.41 & 11.70 & 9.99 & 10.36 & 12.70 \\
\hline & [1.47] & [1.52] & {$[0.80]$} & {$[0.84]$} & {$[1.14]$} \\
\hline Observations & 4789 & 4789 & 3481 & 3481 & 3481 \\
\hline Adjusted-R ${ }^{2}$ & 18.17 & 18.16 & 21.62 & 21.58 & 10.64 \\
\hline
\end{tabular}

a Significant at $1 \%$.

b Significant at $5 \%$.

c Significant at $10 \%$.

Ownership structure (public versus private firm) is a factor that affects the bargaining power of the bidder and target firms in a merger and thus, the stock price responses to a merger announcement. Specifically, ownership structures of bidder and target firms affect the liquidity of shares and access to capital markets. Thus, public bidders (or targets) secure more value for their shareholders because their bargaining power relative to private firms is higher. Indeed, Bradley and Sundaram (2006) find that bidder returns are lower when the target is a public firm. We define bidder (target) status as a dummy variable equal to one if the target (bidder in Table 6) firm is a private firm and zero otherwise. From Table 5, we see that target status is positive and significant in explaining bidder CARs, i.e., if the target is a private firm, bidder CARs are significantly higher. Thus, the results indicate that private firms may have lower bargaining power in negotiating merger deals.

The last regression in Table 5 benchmarks the results of a single-equation model by including all regressors except for the surprise instruments. Comparing regressions 4 (with surprise instruments) and 5 (without surprise instruments), the adjusted- $\mathrm{R}^{2}$ in regression 5 (3.99) is much smaller than that in regression 4 (30.15). This finding supports the hypothesis that anticipations about bidder candidacy contribute to our understanding of stock price responses to merger announcements. A single-equation model is not as powerful in explaining stock price responses as the two-stage model.

\subsection{Regressions of target cumulative abnormal returns}

Table 6 reports regression results of the 3-day CAR for target firms at the merger announcement. The setup for Table 6 (for target firms) is identical to that for Table 5 (for bidder firms). The results for the control variables in Table 6 are similar to those in Table 5 for bidders with three exceptions: i) relative size is positive and significant, ii) deal value is insignificant for target firms, and iii) if the bidder is private, target CARs are significantly lower.

More importantly, in all regressions in Table 6, the coefficients on the surprise instrument are negative and statistically significant, while the coefficients on the interaction term are positive and highly significant. The coefficients on the surprise instrument for positive deals (the sum of the two coefficients) are positive and significant. Thus, as we find for the bidders, the magnitude of the target CARs is affected by whether the merger announcement is a surprise or not. For negative CAR deals, the surprise is a bad surprise and as the surprise instrument increases (i.e., the surprise increases), CAR decreases and becomes even more negative. For positive CAR deals, the surprise is a good surprise and as the surprise instrument increases (i.e., the surprise 
increases), CAR increases and becomes even more positive (sum of two coefficients is positive). Thus, the more surprised the market is about a merger deal, the greater is the impact of the announcement on target stock prices.

\subsection{Investor anticipations of merger candidacy and CARs}

A crucial assumption in merger announcement event studies is that investors learn merger-related information in a short window of time. However, we find that there is anticipation of bidder candidacy. As a result, some merger-related information is stale at the time of announcements. Further, we find that there is less anticipation of target candidacy. Thus, the information that merger announcements reveal about targets is less stale. As a consequence of the difference in the freshness of information revealed at a merger announcement, it is not surprising that previous research has found that target firm CARs are larger in magnitude than bidder CARs. Without controlling for differences in predictability of merger candidacy, it is incorrect to conclude that target shareholders capture the majority of the value gains that mergers generate.

Our findings indicate that, at least to some extent, the asymmetry in investor anticipations about bidder and target candidacy drives the disparity in bidder and target announcement period abnormal returns. To further investigate the disparity between bidder and target CARs, we classify bidder and target firms into 7 categories according to the predicted probability of proposing and receiving a merger bid, obtained from regression Eq. (6). For example, CARs for bidder firms with a 0-3\% predicted probability of proposing a merger are compared against CARs for target firms with a $0-3 \%$ predicted probability of receiving a merger proposal. The results are reported in Panel A of Table 7.

From Table 7, we see that bidder firm CARs decrease as the predicted probability of proposing a merger bid increases. For example, the CAR for bidder firms with a predicted probability of proposing a merger between 0 and $3 \%$ is $3.82 \%$, while for bidders with a predicted probability greater than $25 \%$ is $-0.36 \%$. The difference is significant at $1 \%$. The decrease in target CARs as the predicted probability of receiving bids increases is not as smooth, but is nevertheless decreasing. The CAR for target firms with a predicted probability of proposing a merger between 0 and $3 \%$ is $19.64 \%$, while for targets with a predicted probability greater than $25 \%$ is $10.99 \%$. The difference is significant at $1 \%$.

To see the importance of predictability, we can look at the deals in which the identity of both the bidder and target are a surprise. The difference in CARs for bidder and target firms with a predicted probability of proposing and soliciting a merger between 0 and $3 \%$ is $15.82 \%$, while the sample average is $18.78 \%$. The difference is significant at $1 \%$. Thus, when both the bidder and target is unanticipated, the difference in CARs is significantly smaller than when either party is anticipated as a merger candidate. Further, the market has not impounded the affects of the merger in both the bidder's and target's price. The average probability to propose and receive a bid in the sample is 14.34 and $4.55 \%$, respectively. The average CAR for bidders with predicted probabilities between 14 and $25 \%$ is $0.02 \%$ and the average CAR for targets with predicted probabilities between 4 and $6 \%$ is $19.70 \%$. The mean difference is $19.68 \%$, significant at $1 \%$. Thus, when the bidder is anticipated and the target is not, the difference in CARs is large. The market has already impounded affects of the merger in the bidder's price. But the merger is less anticipated for the target, so the market reaction is larger. However, when both bidder and target firms are equally unanticipated as merger candidates, the difference in CARs is smaller. Panel B of Table 7 shows that when we control for investor anticipations in merger announcements, the difference in CARs is reduced by $1.90 \%$ (18.78-16.88). The difference is significant at $1 \%$. Thus, the evidence supports our hypothesis that to some extent the asymmetry in investor anticipations of merger parties causes disparity in bidder and target firm announcement period abnormal returns.

Table 7

The merger announcement CARs for equally-anticipated bidders and targets. This table classifies bidder and target firms into 7 categories according to the predicted probability of proposing and receiving bids. Panel A reports bidder and target 3-day CARs, differences in bidder and target firm 3-day CARs, and the number of bidders and targets in each category. Panel B reports the average difference CARs across the 7 categories. The first row in Panel B reports the averages for the 7 categories, the average of differences in the 7 categories, and the number of bidders and targets. The second row in Panel B reports the CARs across all deals, the difference in CARs across all deals, and the number of bidders and targets.

\begin{tabular}{|c|c|c|c|c|c|}
\hline Predicted probabilities & Mean bidder CARs (\%) & Mean target CARs (\%) & Difference in mean CARs (\%) & Number of bidders & Number of targets \\
\hline \multicolumn{6}{|c|}{ Panel A - Comparison of CARs for equally-anticipated bidders and targets } \\
\hline $0-3 \%$ & 3.82 & 19.64 & 15.82 & 400 & 795 \\
\hline $3-4 \%$ & 1.54 & 19.73 & 18.20 & 513 & 655 \\
\hline $4-6 \%$ & 0.57 & 19.70 & 19.13 & 768 & 579 \\
\hline $6-9 \%$ & 0.64 & 18.47 & 17.83 & 970 & 323 \\
\hline $9-14 \%$ & -0.11 & 18.43 & 18.54 & 718 & 83 \\
\hline $14 \%-25 \%$ & 0.02 & 17.34 & 17.32 & 726 & 38 \\
\hline Over $25 \%$ & -0.36 & 10.99 & 11.35 & 694 & 9 \\
\hline \multicolumn{6}{|c|}{ Panel B - Difference in bidder and target CARs averaged across all categories and all deals } \\
\hline Average of 10 categories & 0.87 & 17.76 & 16.88 & 4789 & 2482 \\
\hline All deals & 0.64 & 19.42 & 18.78 & 4789 & 2482 \\
\hline
\end{tabular}


Table 8

Difference in CARs for deals with the most and least evenly matched bidder and target probabilities. This table classifies bidder and target firms according to whether the predicted probabilities for the bidder and target are evenly matched. The deals are identified as most evenly matched (least evenly matched) if the difference in predicted probabilities is in the lowest (highest) twenty-fifth percentile and the fiftieth percentile. The table only considers bidder and target pairs for which probabilities and CARs for both parties to the merger are available. Table reports averages for differences in bidder and target firm predicted probabilities, differences in 3-day CARs, and the number of deals in each category.

\begin{tabular}{lll}
\hline Difference in predicted probabilites for bidder and target & Most evenly matched & In-between match \\
\hline Difference in probabilities (top versus bottom 25\%) & Less than 2.11\% & Greater than 2.11\% and less than $11.82 \%$ \\
Mean difference in 3-day CAR & $20.80 \%$ & $22.99 \%$ \\
N & 227 & 453 \\
Difference in probabilities (top versus bottom 50\%) & Less than $4.99 \%$ & \\
Mean difference in 3-day CAR & $20.50 \%$ & \\
N & 454 & \\
\hline
\end{tabular}

In contrast to Table 7 which classifies bidders and targets into 7 probability bins regardless of whether the bidder and target paired in the merger, Table 8 considers the 907 deals for which we have bidders and targets of the same merger. Specifically, in Table 8 we examine deals in which the predicted probability to bid for the bidder and the predicted probability to receive a bid for the target are most and least evenly matched. We then rank mergers based on the difference in predicted probabilities for the bidder and target firms involved in the merger. As seen in Table 8, we classify a merger as most and least evenly matched using two cutoffs: 1) the difference in predicted probabilities is in the bottom 25th percentile in the difference ranking (most evenly matched) and in the top 25th percentile (least evenly matched); and 2 ) the difference in predicted probabilities is in the bottom 50th percentile in the difference ranking (most evenly matched) and in the top 50th percentile (least evenly matched). Table 8 reports the mean differences in bidder and target firm predicted probabilities, the mean differences in three-day CARs, and the number of deals in each category. Table 8 shows that using the $25 \%$ cutoff for identifying most evenly matched bidders and targets, the mean difference in predicted probabilities is less than $2.11 \%$ and the mean difference in bidder and target 3 -day CARs is $20.80 \%$. These are the mergers in which investors anticipate bidder and target candidacy most evenly. In contrast, using the 25\% cutoff for identifying least evenly matched bidders and targets, the mean difference in predicted probabilities is greater than $11.82 \%$ and the mean difference in bidder and target 3-day CAR is $25.34 \%$. These are the deals in which the greatest disparity in anticipation of bidder and target candidacy exists. The difference in mean CARs for least evenly matched deals (25.34\%) is significantly greater than the difference for most evenly matched deals (20.80\%) at 5\%. Using the $50 \%$ cutoff for identifying most evenly matched bidders and targets, the mean difference in predicted probabilities is less than $4.99 \%$ and the mean difference in bidder and target 3-day CARs is $20.50 \%$. Using the $50 \%$ cutoff for identifying least evenly matched bidders and targets, the mean difference in predicted probabilities is greater than $4.99 \%$ and the mean difference in bidder and target 3-day CAR is 25.57\%. The difference in mean CARs for least evenly matched deals is significantly greater than the difference for most evenly matched deals at $1 \%$. The results show that as the disparity in anticipation about bidder and target candidacy widens so does the difference in bidder and target 3-day CARs.

\section{Conclusion}

This paper investigates the extent to which investors anticipate bidder and target merger candidacy and if investor anticipations about candidacy affect the distribution of value between bidder and target firm shareholders. Using a twostage multinomial framework, we investigate if and how investor anticipation of merger candidacy affects abnormal returns that are measured around merger announcements. We find that investors can predict bidder firms more successfully than target firms. To investigate how value is distributed among bidder and target shareholders, we control for different degrees of predictability in bidder and target selection. Once we account for greater predictability in bidder firm candidacy, the difference between bidder and target firm three-day cumulative abnormal returns around a merger announcement decreases significantly. Thus, the evidence supports the hypothesis that to some extent the asymmetry in investor anticipations of merger parties causes disparity in bidder and target firm announcement period abnormal returns.

\section{Acknowledgments}

This paper is based on the dissertation of Başak Tanyeri completed at the Carroll School of Business, Boston College. The authors are grateful to Ed Kane, Phil Strahan and seminar participants at the Financial Management Association Annual Meetings, the Eastern Finance Association Annual Meetings, Midwest Finance Association Annual Meetings, the Southwest Finance Association Annual Meetings, METU Muhan Soysal Conference, Boston College, Southern Illinois University at Carbondale, Humboldt State University, Bilkent University, Sabancı University, TOBB ETU, and an anonymous referee for their helpful comments. 


\section{Appendix A. Descriptive statistics of variables used to predict bidder and target firm merger candidacy}

This table lists descriptive statistics for the variables used to predict bidder and target firm merger candidacy and management's motives for a merger. The sample covers 26 years from 1979 to 2004. Based on SDC announcement dates for the merging firm sample, a firm is identified as a bidder firm in a given year if it proposes at least one bid in the next financial statement release year (Panel A), a firm is identified as a target firm if it solicits at least one bid in the next year (Panel B), and a firm is identified as a non-merging firm in a given year if it neither proposes nor solicits a bid in the next year (Panel C). Panel D reports statistics for the full sample.

\begin{tabular}{|c|c|c|c|c|c|}
\hline & Mean & Median & Standard deviation & Minimum & Maximum \\
\hline \multicolumn{6}{|l|}{ Panel A - bidders } \\
\hline Sales shock (\%) & 13.34 & 9.80 & 13.61 & 0.00 & 170.40 \\
\hline Sales shock squared (\%) & 3.63 & 0.96 & 10.85 & 0.00 & 290.35 \\
\hline Size (millions of $\$$ s) & 2703 & 282 & 10,564 & 0.00 & 243,283 \\
\hline Change in size (\%) & 65.03 & 27.41 & 135.20 & -86.33 & 1740.29 \\
\hline Sales growth (\%) & 63.56 & 26.61 & 145.04 & -100.00 & 1863.80 \\
\hline Concentration ratio (\%) & 58.28 & 57.37 & 19.50 & 13.62 & 100.00 \\
\hline Resource-growth-mismatch & 0.47 & 0.00 & 0.50 & 0.00 & 1.00 \\
\hline ROA (\%) & 0.04 & 5.04 & 25.53 & -435.61 & 28.14 \\
\hline Share turnover (\%) & 123.39 & 81.35 & 120.29 & 0.43 & 630.90 \\
\hline Cash ratio (\%) & 9.23 & 4.04 & 12.33 & 0.00 & 83.68 \\
\hline Previous mergers & 0.60 & 0.00 & 1.24 & 0.00 & 26 \\
\hline Dormant period (months) & 4.22 & 1.00 & 10.68 & 1.00 & 172 \\
\hline Price run-up (\%) & 42.80 & 12.50 & 133.60 & -96.06 & 1300.00 \\
\hline Information asymmetry & 0.15 & 0.00 & 0.36 & 0.00 & 1.00 \\
\hline \multicolumn{6}{|l|}{ Panel B - targets } \\
\hline Sales shock (\%) & 13.85 & 10.18 & 14.19 & 0.00 & 123.92 \\
\hline Sales shock squared (\%) & 3.93 & 1.04 & 10.56 & 0.00 & 153.56 \\
\hline Size (millions of $\$$ s) & 920 & 97 & 4009 & 0.00 & 86,972 \\
\hline Change in size (\%) & 33.78 & 12.92 & 103.97 & -86.14 & 1412.84 \\
\hline Sales growth (\%) & 41.73 & 17.05 & 122.97 & -100.00 & 1881.75 \\
\hline Concentration ratio (\%) & 57.75 & 56.90 & 19.19 & 13.62 & 100.00 \\
\hline Resource-growth-mismatch & 0.49 & 0.00 & 0.50 & 0.00 & 1.00 \\
\hline ROA (\%) & -5.91 & 2.71 & 29.53 & -339.09 & 28.17 \\
\hline Share turnover (\%) & 105.22 & 71.77 & 104.78 & 0.37 & 635.12 \\
\hline Cash ratio (\%) & 8.66 & 3.20 & 12.25 & 0.00 & 85.46 \\
\hline Previous mergers & 0.29 & 0.00 & 0.71 & 0.00 & 8.00 \\
\hline Dormant period (months) & 3.89 & 1.00 & 9.47 & 1.00 & 166 \\
\hline Price run-up (\%) & 16.73 & -4.24 & 106.43 & -95.98 & 1155.71 \\
\hline Information asymmetry & 0.13 & 0.00 & 0.34 & 0.00 & 1.00 \\
\hline \multicolumn{6}{|l|}{ Panel $C$ - non-merging firms } \\
\hline Sales shock (\%) & 12.70 & 9.36 & 14.59 & 0.00 & 786.07 \\
\hline Sales shock squared (\%) & 3.74 & 0.88 & 49.94 & 0.00 & 6179.05 \\
\hline Size (millions of $\$$ s) & 1532 & 100 & 8728 & 0.00 & 750,507 \\
\hline Change in size (\%) & 34.06 & 14.02 & 102.11 & -87.09 & 1777.51 \\
\hline Sales growth (\%) & 41.35 & 16.96 & 130.19 & -100.00 & 2026.92 \\
\hline Concentration ratio (\%) & 59.00 & 58.60 & 20.32 & 13.62 & 100.00 \\
\hline Resource-growth-mismatch & 0.48 & 0.00 & 0.50 & 0.00 & 1.00 \\
\hline ROA (\%) & -6.57 & 2.85 & 35.64 & -504.40 & 28.17 \\
\hline Share turnover (\%) & 80.04 & 48.90 & 92.43 & 0.36 & 635.03 \\
\hline Cash ratio (\%) & 8.67 & 3.42 & 12.71 & 0.00 & 86.12 \\
\hline Previous mergers & 0.12 & 0.00 & 0.43 & 0.00 & 11 \\
\hline Dormant period (months) & 6.08 & 2.00 & 13.85 & 1.00 & 177 \\
\hline Price run-up (\%) & 24.47 & -2.13 & 123.12 & -96.26 & 1302.56 \\
\hline Information asymmetry & 0.19 & 0.00 & 0.39 & 0.00 & 1.00 \\
\hline \multicolumn{6}{|l|}{ Panel D - All firms } \\
\hline Sales shock (\%) & 12.76 & 9.43 & 14.54 & 0.00 & 786.07 \\
\hline Sales shock squared (\%) & 3.74 & 0.89 & 48.02 & 0.00 & 6179.05 \\
\hline Size (millions of $\$$ s) & 1574 & 105 & 8736 & 0.00 & 750,507 \\
\hline Change in size (\%) & 35.61 & 14.59 & 104.30 & -87.09 & 1777.51 \\
\hline Sales growth (\%) & 42.48 & 17.41 & 130.86 & -100.00 & 2026.92 \\
\hline Concentration ratio (\%) & 58.93 & 58.48 & 20.25 & 13.62 & 100.00 \\
\hline Resource-growth-mismatch & 0.48 & 0.00 & 0.50 & 0.00 & 1.00 \\
\hline ROA $(\%)$ & -6.22 & 2.97 & 35.07 & -504.40 & 28.17 \\
\hline Share turnover (\%) & 82.94 & 51.12 & 94.95 & 0.36 & 635.12 \\
\hline Cash ratio (\%) & 8.70 & 3.44 & 12.68 & 0.00 & 86.12 \\
\hline Previous mergers & 0.15 & 0.00 & 0.52 & 0.00 & 26 \\
\hline Dormant period (months) & 5.92 & 1.00 & 13.61 & 1.00 & 177 \\
\hline Price run-up (\%) & 25.17 & -1.40 & 123.29 & -96.26 & 1302.56 \\
\hline Information asymmetry & 0.18 & 0.00 & 0.39 & 0.00 & 1.00 \\
\hline
\end{tabular}




\section{Appendix B. Description of variables used to explain merger announcement cumulative abnormal returns}

This table lists descriptive statistics for the variables used to explain merger announcement cumulative abnormal returns. The sample covers 26 years from the 1979 through 2004. Based on SDC announcement dates for the merging firm sample, a firm is identified as a bidder firm in a given year if it proposes at least one bid in the next financial statement release year (Panel A) and firm is identified as a target firm if it receives at least one bid in the next year (Panel B). Panel C reports statistics for the bidders and targets together.

\begin{tabular}{|c|c|c|c|c|c|}
\hline & Mean & Median & Standard deviation & Minimum & Maximum \\
\hline \multicolumn{6}{|l|}{ Panel A - bidders } \\
\hline All equity & 0.24 & 0.00 & 0.43 & 0.00 & 1.00 \\
\hline Anti-takeover defense & 0.01 & 0.00 & 0.08 & 0.00 & 1.00 \\
\hline Unwelcoming attitude & 0.03 & 0.00 & 0.17 & 0.00 & 1.00 \\
\hline Target bankrupt & 0.01 & 0.00 & 0.09 & 0.00 & 1.00 \\
\hline Target status & 0.50 & 0.00 & 0.50 & 0.00 & 1.00 \\
\hline Same industry & 0.32 & 0.00 & 0.47 & 0.00 & 1.00 \\
\hline Same state & 0.24 & 0.00 & 0.43 & 0.00 & 1.00 \\
\hline Deal value (billions of $\$$ ) & 0.49 & 0.05 & 2.69 & 0.00 & 89.17 \\
\hline Relative value (\%) & 0.39 & 0.12 & 0.73 & 0.00 & 8.06 \\
\hline \multicolumn{6}{|l|}{ Panel B - targets } \\
\hline All equity & 0.25 & 0.00 & 0.43 & 0.00 & 1.00 \\
\hline Anti-takeover defense & 0.02 & 0.00 & 0.14 & 0.00 & 1.00 \\
\hline Unwelcoming attitude & 0.10 & 0.00 & 0.30 & 0.00 & 1.00 \\
\hline Target bankrupt & 0.01 & 0.00 & 0.09 & 0.00 & 1.00 \\
\hline Bidder status & 0.09 & 0.00 & 0.29 & 0.00 & 1.00 \\
\hline Same industry & 0.34 & 0.00 & 0.47 & 0.00 & 1.00 \\
\hline Same state & 0.22 & 0.00 & 0.42 & 0.00 & 1.00 \\
\hline Deal value (billions of $\$$ ) & 1.11 & 0.12 & 5.43 & 0.00 & 164.75 \\
\hline Relative value (\%) & 1.80 & 1.61 & 1.01 & 0.04 & 8.11 \\
\hline \multicolumn{6}{|l|}{ Panel C - all firms } \\
\hline All equity & 0.24 & 0.00 & 0.43 & 0.00 & 1.00 \\
\hline Anti-takeover defense & 0.01 & 0.00 & 0.10 & 0.00 & 1.00 \\
\hline Unwelcoming attitude & 0.05 & 0.00 & 0.23 & 0.00 & 1.00 \\
\hline Target bankrupt & 0.01 & 0.00 & 0.09 & 0.00 & 1.00 \\
\hline Status & 0.36 & 0.00 & 0.48 & 0.00 & 1.00 \\
\hline Same industry & 0.33 & 0.00 & 0.47 & 0.00 & 1.00 \\
\hline Same state & 0.23 & 0.00 & 0.42 & 0.00 & 1.00 \\
\hline Deal value (billions of \$) & 0.73 & 0.07 & 4.00 & 0.00 & 164.75 \\
\hline Relative value (\%) & 0.94 & 0.51 & 1.10 & 0.00 & 8.11 \\
\hline
\end{tabular}

\section{References}

Aktas, N., de Bodt, E., Roll, R., 2009. Learning, hubris and corporate serial acquisitions. J. Corp. Fin. 15, 543-561.

Ambrose, B.W., Megginson, W.L., 1992. The role of asset structure, ownership structure, and takeover defenses in determining acquisition likelihood. J. Financ. Quant. Anal. 27, 575-589.

Andrade, G., Mitchell, M.L., Stafford, E., 2001. New evidence and perspectives on mergers. J. Econ. Perspect. 15, $103-120$.

Asquith, P., Bruner, R.F., Mullins, D.V., 1983. The gains to bidding firms from merger. J. Financ. Econ. 11, 121-139.

Betton, S., Eckbo, B.E., Thorburn, K.S., 2009. Markup Pricing Revisited. Available at SSRN. http://ssrn.com/abstract=1094946.

Bhagat, S., Dong, M., Hirshleifer, D., Noah, R., 2005. Do tender offers create value? New methods and evidence. J. Financ. Econ. 76, 3-60.

Billett, M.T., Qian, Y., 2008. Are overconfident CEOs born or made? Evidence of self-attribution bias from frequent acquirers. Manage. Sci. 54, 1037-1051.

Bradley, M., Sundaram, A.K., 2006. Acquisitoins and Performance: a Re-assessment of the Evidence. Available at SSRN. http://ssrn.com/abstract=592761.

Campa, J.M., Kedia, S., 2002. Explaining the diversification discount. J. Finance 57, 1731-1762.

Chakrabarti, R., 2005. Mars-Venus Marriages: Culture and Cross-border M and A. European FMA Meeting, Siena.

Cremers, K.J.M., Nair, V.B., John, K., 2009. Takeovers and cross-section of returns. Rev. Financ. Stud. 22, 1409-1445.

Eckbo, B.E., 1992. Mergers and the value of antitrust deterrence. J. Finance 47, 1005-1029.

Eckbo, B.E., Maksimovic, V., Williams, J., 1990. Consistent estimation of cross-sectional models in event studies. Rev. Financ. Stud. 3, $343-365$.

Edmans, A., Goldstein, I., Jiang, W., 2009. Takeover Activity and Target Valuations: Feedback Loops in Financial Markets. Working paper, Wharton School of Business. Fluck, Z., Lynch, A.W., 1999. Why do firms merge and then divest? A theory of financial synergy. J. Bus. 72, 319-346.

Fuller, K., Netter, J., Stagemoller, M., 2002. What do returns to acquiring firms tell us? Evidence from firms that make many acquisitions? J. Finance 57, $1763-1793$. Gort, M., 1969. An economic disturbance theory of mergers. Q. J. Econ. 83, 624-642.

Hansen, R., 1987. A theory for the exchange medium in mergers and acquisitions. J. Bus. 60, 75-95.

Harford, J., 1999. Corporate cash reserves and acquisitions. J. Finance 54, 1969-1997.

Harford, J., Mansi, S.A., Maxwell, W.F., 2008. Corporate governance and firm cash holdings in the U.S. J. Financ. Econ. 87, 535-555.

Heckman, J.J., 1979. Sample selection bias as a specification error. Econometrica 47, 153-162.

Hietala, P., Kaplan, S.N., Robinson, D.T., 2003. What is the price of hubris? Using takeover battles to infer overpayments and synergies. Financ. Manage. 32, 5-31. Holmes, T.J., Schmitz, J.A., 1995. On the turnover of business firms and business managers. J. Polit. Econ. 103, $1005-1038$.

Ismail, A., 2005. Will Multiple Acquirers Ever Learn: the US Evidence from Single Versus Multiple Acquirers? American University of Beirut, Working paper.

Jarrell, G.A., Brickley, J.A., Netter, J.M., 1988. The market for corporate control: the empirical evidence since 1980. J. Econ. Perspect. 2, 49-68.

Jennings, R.H., Mazzeo, M.A., 1993. Competing bids, target management resistance, and the structure of takeover bids. Rev. Financ. Stud. 6, 883-909.

Jensen, M.C., 2005. Agency costs of overvalued equity. Financ. Manage. 34, 5-15.

Jensen, M.C., Ruback, R.S., 1983. The market for corporate control: the scientific evidence. J. Financ. Econ. 11, 5-50. 
Jovanovic, B., Rousseau, P.L., 2002. The Q-theory of mergers. Am. Econ. Rev. 92, 198-204.

Kedia, S., Panchapagesan, V., Uysal, V., 2005. Geography and Acquirer Returns. Available at SSRN. http://ssrn.com/abstract=871513.

Lang, L.H.P., Stulz, R.M., Walkling, R.A., 1989. Managerial performance, Tobin's q and the gains from successful tender offers. J. Financ. Econ. $24,137-154$.

Lee, L., 1982. Some approaches to the correction of selectivity bias. Rev. Econ. Stud. 49, 355-372.

Lee, L., 1983. Generalized econometric models with selectivity. Econometrica 51, 507-512.

Loderer, C., Martin, K., 1990. Corporate acquisitions by listed firms. Financ. Manage. 19, 17-33.

Maksimovic, V., Phillips, G., 2001. The market for corporate assets: who engages in mergers and asset sales and are there efficiency gains? J. Finance 56, $2019-2065$.

Malatesta, P., Thomson, R.A., 1985. Partially anticipated events. J. Financ. Econ. 14, 237-250.

Mitchell, M.L., Mulherin, H.J., 1996. The impact of industry shocks on takeover and restructuring activity. J. Financ. Econ. 41, 193-229.

Moeller, S.B., Schlingenmann, F., Stulz, R.M., 2004. Firm size and the gains from acquisitions. J. Financ. Econ. 73, 201-228.

Moeller, S.B., Schlingenmann, F., Stulz, R.M., 2005. Wealth destruction on a massive scale: a study of acquiring-firm returns in the recent merger wave. J. Finance 60, 757-782.

Myers, S., Majluf, N., 1984. Corporate financing and investment decisions when firms have information that investors do not have. J. Financ. Econ. 13, 187-221.

Netter, J., Stegemoller, M., Wintoki, M.B., 2010. A Study of Over 250,000 (or less) Mergers and Acquisitions from 1992-2009. Available at SSRN. http://ssrn.com/ abstract $=1510724$

Palepu, K.G., 1986. Predicting takeover targets. J. Acct. Econ. 8, 3-35.

Rhoades-Kropf, M., Viswanathan, S., 2004. Market valuation and merger waves. J. Finance 59, 2685-2718.

Schwert, G.W., 1996. Markup pricing in mergers and acquisitions. J. Finan. Econ. 41, 153-192.

Shipper, K., Thompson, R.A., 1983. Evidence on the capitalized value of merger activity for acquiring firms. J. Financ. Econ. 11, 85-119.

Song, M.H., Walkling, R.A., 2000. Abnormal returns to rivals of acquisition targets: a test of the 'acquisition probability hypothesis. J. Financ. Econ. 55 (2), $143-172$.

Song, M.H., Walkling, R.A., 2008. Anticipation, Acquisitions and Bidder Returns: Industry Shocks and the Transfer of Information Across Rivals. Available at SSRN. http://ssrn.com/abstract=698142.

Villalonga, B., 2004. Does diversification cause the diversification discount? Financ. Manage. 33 (2), 5-27.

White, H., 1980. A heteroscedasticity-consistent covariance matrix estimator and a direct test for heteroscedasticity. Econometrica 48, 817-838. 